\title{
Inhibition of carrageenan-induced expression of tissue and plasma prekallikreins mRNA by low level laser therapy in a rat paw edema model
}

\author{
Inibição da expressão de RNA mensageiro de pré-calicreínas tecidual e \\ plasmática pela laserterapia em modelo de edema de pata induzido pela \\ carragenina em ratos
}

Moisés P. Silva', Flávia Bortone', Marcelo P. Silva', Thiago R. Araújo', Maricília S. Costa², José A. Silva Júnior'

\begin{abstract}
Background: Low level laser therapy (LLLT) has been used clinically in order to treat inflammation, where tissue and plasma prekallikrein have crucial importance. Plasma prekallikrein (PPK) is synthesized by the hepatocytes and secreted into the bloodstream, where it participates in the surface-dependent activation of blood coagulation, fibrinolysis, kinin generation and inflammation. Tissue prekallikrein is associated with important disease states (including cancer, inflammation, and neurodegeneration) and has been utilized or proposed as clinically important biomarker or therapeutic target of interest. Objective: To evaluate if LLLT modulates tissue and plasma prekallikreins mRNA expression in the carrageenan-induced rat paw edema. Methods: Experimental groups were assigned as followed: $A_{1}$ (Control-saline), $A_{2}$ (Carrageenan-only), $A_{3}$ (laser 660nm only) and $A_{4}$ (Carrageenan + laser 660nm). Edema was measured by a plethysmometer. Subplantar tissue was collected for the quantification of prekallikreins mRNA by Real time-Polymerase Chain Reaction. Results: A significantly decrease in the edema was observed after laser irradiation. Expression of prekallikreins increased after carrageenan injection. Tissue and plasma prekallikrein mRNA expression significantly decreased after LLLT's 660nm wavelength. Conclusion: These results suggest that expression of tissue and plasma prekallikreins is modulated by LLLT, which can be used in clinical practice due to its anti-inflammatory effects.
\end{abstract}

Key words: Plasma kallikrein; tissue kallikrein; low-level laser therapy; gene expression; inflammation.

\section{Resumo}

Contextualização: A laserterapia de baixa potência tem sido usada para o tratamento de processos inflamatórios diversos em que a calicreína tecidual e a plasmática possuem participação ativa. A pré-calicreína plasmática (PPK) é sintetizada pelos hepatócitos e secretada na corrente sanguínea, onde participa da ativação da coagulação, fibrinólise, geração de cininas e inflamação. A précalicreína tecidual está associada com importantes doenças (incluindo câncer, inflamação e neurodegeneração) e tem sido utilizada ou sugerida clinicamente como importante biomarcador ou alvo terapêutico. Objetivo: Avaliar se a laserterapia altera a expressão gênica da pré-calicreína tecidual e da plasmática no modelo de inflamação aguda induzida pela carragenina. Métodos: Quarenta ratos foram separados em quatro grupos experimentais: $A_{1}$ (controle), $A_{2}$ (carragenina, apenas), $A_{3}$ (laser 660nm, apenas) e $A_{4}($ Carragenina + laser 660nm). O edema foi medido por um pletismômetro. Tecido subplantar foi coletado para a quantificação de RNA mensageiro (RNAm) de pré-calicreínas tecidual e plasmática por PCR em tempo real. Resultados: Observou-se uma diminuição significativa no volume de edema após irradiação com laser 660nm. A expressão de RNAm de pré-calicreínas tecidual e plasmática aumentou após a inoculação de carragenina, entretanto a expressão gênica das pré-calicreínas diminuiu significantemente após laserterapia de baixa potência de 660nm. Conclusão: Os resultados sugerem que a expressão de RNAm das pré-calicreínas tecidual e plasmática é modulada pela laserterapia de baixa potência, podendo ser alvo terapêutico para tratamento de processos inflamatórios.

Palavras-chave: calicreína plasmática; calicreína tecidual; laserterapia de baixa potência; expressão gênica; inflamação.

Received: 30/06/2009 - Revised: 23/02/2010 - Accepted: 13/10/2010 


\section{Introduction $: \because 8$}

The kallikrein-kinin system is an endogenous metabolic cascade that its activation results in the release of vasoactive kinins (bradykinin-related peptides). This complex system includes the precursors of kinins known as kininogens and mainly tissue and plasma prekallikreins ${ }^{1}$. Kallikreins (KLK) are a family of serine proteases with diverse physiologic functions. Members of this family are associated with important disease states (including cancer, inflammation, and neurodegeneration) and have been utilized or proposed as clinically important biomarkers or therapeutic targets of interest ${ }^{2}$. All KLKs are synthesized as preproforms that are proteolytically processed to secreted pro-forms via the removal of an amino-terminal secretion signal peptide. The secreted inactive pro-KLKs are then activated in extracellular compartment to mature peptidases by specific proteolytic release of their amino-terminal propeptide ${ }^{3,4}$.

Tissue kallikreins are serine proteases that are encoded by highly conserved multigene family clusters in rodents and humans ${ }^{5}$. Tissue kallikreins are expressed, to varying degrees, in a wide range of tissues suggesting a functional involvement in a diverse range of physiological and pathophysiological processes, which include roles in normal skin desquamation and psoriatic lesions, tooth development, neural plasticity, and Alzheimer's disease. Particular interest is the expression level of many kallikreins in prostate, ovarian and breast cancers, where they are emerging as useful prognostic indicators of disease progression ${ }^{6}$. Inflammatory processes such as arthritis and acute joint inflammation also are dependent of kallikrein activation via proteinase-activated receptor 4 (PAR-4) $)^{7,8}$.

Plasma prekallikrein (PPK) is synthesized by the hepatocytes and secreted into the bloodstream, where it participates in the surface-dependent activation of blood coagulation, fibrinolysis, kinin generation and inflammation. Human PPK gene is transcribed not only in the liver, but also in various nonhepatic human tissues at significant levels .

Carrageenan injection is a widely model used to induce acute inflammatory response in experimental animals that induces the release of different inflammatory mediators, such as histamine, bradykinin, prostaglandins and superoxide anions ${ }^{10}$. Winter, Risley and Nuss ${ }^{11}$ described the use of carrageenan as an irritant agent to induce rodents paw edema, and is a popular method for testing new anti-inflammatory therapies ${ }^{12,13}$.

The use of laser by physical therapists has allowed the treatment of several inflammatory disorders. The association of carrageenan administration and low level laser therapy is becoming one important tool for studying healing inflammatory conditions. Generally associated with anti-inflammatory effects, pain relief and accelerate the regeneration in the damage tissue ${ }^{14,15}$, low level laser therapy (LLLT) using near infrared irradiation (600-1,000nm) has been used to treat patients with inflammatory processes. The clinical use of LLLT in the conventional medicine has been recently suggested ${ }^{16}$. The general belief is that laser light directs biostimulative energy to the body's injured cells in a specific location, where the cells transform this energy into chemical energy promoting natural healing and pain relief through tissue repair. Interestingly, the understanding of the molecular mechanism by which laser action can successfully ameliorate inflammatory states is not clearly understood.

Therapeutic laser has been widely used in several studies to demonstrate its potential anti-inflammatory effects. In 1992, Honmura et al. ${ }^{17}$ studying the effect of a $780 \mathrm{~nm}$ Ga-Al-As diode laser irradiation observed that laser inhibited the increase of vascular permeability during the occurrence of an acute inflammation in the carrageenan-air-pouch model, the edema in the acute stage in the carrageenan-paw-edema model, and the granuloma formation in the carrageenan-granuloma model after receiving laser irradiation once daily ${ }^{17}$. Recently, de Morais et al..$^{18}$ showed that LLLT also reduces inflammatory signs effectively in an animal model of zymosan-induced arthritis ${ }^{18}$. Furthermore, Boschi et al. ${ }^{19}$, in 2008, found that LLLT-660 nm can induce an anti-inflammatory effect characterized by inhibition of total or differential leukocyte influx, exudation, total protein, NO, IL-6, MCP-1, IL-10, and TNF-alpha, in a dose-dependent manner ${ }^{19}$. Beneficial effects of LLLT usage against inflammation in dentistry were reported on root canal walls, periodontal tissues, and endodontics as reviewed by Mohammadi ${ }^{20}$.

The present study was designed to investigate the anti-inflammatory effects of LLLT, applied in a wavelength of 660nm, and the participation of tissue and plasma prekallikreins in this therapeutic action using a state-of-art technology.

\section{Methods $: \because$.}

\section{Animals}

The experiments were performed using male Wistar rats (150-200g), with food and water "ad libitum" provided by Central Animal House of the Research and Development Department of Universidade Vale do Paraíba (UNIVAP), São José dos Campos, SP, Brazil. All experiments were carried out in accordance with the guidelines of UNIVAP for animal care (protocol number: A034/2006/CEP). All rats were placed in a common box and randomly allocated into four groups composed by ten rats each.

\section{Induction of the edema}

A single subplantar injection $(0.1 \mathrm{ml})$ of carrageenan (Sigma Chemical Co., St Louis, MO, USA), using a stock concentration 
of $1 \%$ (Saline $0.85 \%$ ) was administered in the rat left hind paw under brief anesthesia with halothane $\mathrm{e}^{21}$.

\section{Laser irradiation}

A continuous, 660-nm, low-intensity GaAlAs diode laser (model: laser unit, Kondortech) was used in this study. The spot size was approximately $0.2 \mathrm{~cm}^{2}$ in diameter in the middle of paw palm area. Laser irradiation with intensity of $30-\mathrm{mW}$ output (energy density of $7.9 \mathrm{~J} / \mathrm{cm}^{2}$, irradiation time of 60 seconds) was applied on the marked spot on the experimental side. Optical power was calibrated using a Newport Multifunction Optical Meter (model 1835C). Stability of laser during laser irradiation was measured collecting light with a partial reflect (4\%). The laser beam illuminated a single spot in a left hind paw of each animal of approximately $0.785 \mathrm{~cm}^{2}$. Each animal received a single irradiation.

\section{Experimental groups}

Forty rats were allocated into four groups $\left[A_{1}\right.$ (Controlsaline), $A_{2}$ (Carrageenan only), $A_{3}$ (laser 660nm only), $A_{4}$ (Carrageenan + laser $660 \mathrm{~nm}$ )]. Animals from $\mathrm{A}_{4}$ group were irradiated at $1^{\text {st }}$ hour after edema induction by carrageenan administration. Each group consisted of 10 animals.

\section{Volume edema}

Volume of the paw edema (ml) was measured in each animal using a plethysmometer (plethysmometer 7150, Ugo Basile, Italy) with a precision of two decimal places. Volume of paw edema was determined immediately before, and 1,2,3 and 4 hours after carrageenan administration. An increase in paw volume $(\mathrm{ml})$ was calculated by subtracting the basal volume from the final volume in each animal ${ }^{22}$.

\section{Experimental procedure}

A considerable increase in the paw volume after carrageenan administration characterized the inflammatory process. Animals were sacrificed by decapitation 4 hours after different treatments and subplantar muscles were quickly dissected, immediately frozen in liquid nitrogen and stocked at $-80^{\circ} \mathrm{C}$, until RNA isolation.

\section{Total RNA extraction}

Total RNA was extracted from thawed tissues homogenized in $1 \mathrm{ml}$ of TRIzol reagent (Gibco BRL, Gaithersburg, MD), accordingly to the manufacturer's instructions.

\section{Quantitative Real-time polymerase chain reaction (RT-PCR)}

One microgram of total RNA was used for cDNA synthesis and RT-PCR gene expression analysis. Initially, contaminating DNA was removed using DNase I (Invitrogen) at a concentration of 1 unit/ $\mu \mathrm{g}$ RNA in the presence of $20 \mathrm{mM}$ Tris-HCl (pH 8.4), containing $2 \mathrm{mM} \mathrm{MgCl}_{2}$ for $15 \mathrm{~min}$ at $37^{\circ} \mathrm{C}$, followed by incubation at $95^{\circ} \mathrm{C}$ during 5 min for enzyme inactivation. The reverse transcription (RT) was carried out in a $200 \mu$ reaction in the presence of $50 \mathrm{mM}$ Tris- $\mathrm{HCl}$ ( $\mathrm{pH} 8.3$ ), $3 \mathrm{mM} \mathrm{MgCl}_{2}$, $10 \mathrm{mM}$ dithiothreitol, $0.5 \mathrm{mM}$ dNTPs and $50 \mathrm{ng}$ of random primers with 200 units of Moloney murine leukemia virus-reverse transcriptase (Invitrogen). The reaction conditions were: $20^{\circ} \mathrm{C}$ for $10 \mathrm{~min}, 42^{\circ} \mathrm{C}$ for $45 \mathrm{~min}$ and $95^{\circ} \mathrm{C}$ for $5 \mathrm{~min}$.

The reaction product was amplified by real time PCR on a 7000 Sequence Detection System (ABI Prism, Applied Biosystems, Foster City, CA) using the SYBRGreen core reaction kit (Applied Biosystems). The thermal cycling conditions were: $50^{\circ} \mathrm{C}$ for $2 \mathrm{~min}$, then $95^{\circ} \mathrm{C}$ for $10 \mathrm{~min}$, followed by 40 cycles at $95^{\circ} \mathrm{C}$ for $15 \mathrm{~s}$ and $60^{\circ} \mathrm{C}$ for $1 \mathrm{~min}$. Experiments were performed in triplicates for each data point. Tissue and plasma prekallikreins mRNA abundance were quantified as a relative value compared with an internal reference, $\beta$-actin, whose abundance was believed not to change between the varying experimental conditions. Primers used for real time PCR were as follows: rat KLK1 (tissue kallikrein) forward primer (GenBank ${ }^{\mathrm{TM}}$ accession number NM_001005382) 5'- tgtcatcaacagatacctctg -3 ' and reverse primer 5'- GCATGATCTGTCACCATCTGT-3'; rat PPK (plasma kallikrein) forward primer $\left(\mathrm{GenBank}^{\mathrm{TM}}\right.$ accession number AH003184) 5'- ctgtattgacaggtcaaaca -3' and reverse primer 5-AGTCTTCACATGAAGCTAGT -3'; and rat $\beta$-actin forward primer (GenBank ${ }^{\mathrm{TM}}$ accession number J00691) 5'- AAGTCCCTCACCCTCCCAAAAG -3' and reverse primer (GenBank ${ }^{\mathrm{TM}}$ accession number V01217) 5'- AAGCAATGCTGTCACCTTCCC -3'. One microliter of RT reaction was used for Real-Time PCR. A preliminary experiment was previous performed to determine if saline inoculation could result in mRNA expression changes.

Quantitative values for the tissue and plasma prekallikreins and $\beta$-actin mRNA transcription were obtained from the threshold cycle number, where the increase in the signal associated with an exponential growth of PCR products begins to be detected. Melting curves were generated at the end of every run to ensure product uniformity. The relative target gene expression level was normalized on the basis of $\beta$-actin expression as an endogenous RNA control. $\Delta$ Ct values of the samples were determined by subtracting the average $C_{\mathrm{t}}$ value of tissue and plasma prekallikreins mRNA from the average $C_{\mathrm{t}}$ value of the internal control $\beta$-actin. As it is uncommon to use $\Delta \mathrm{Ct}$ as 
a relative data due to this logarithmic characteristic, the $2^{-\Delta \mathrm{Ct}}$ parameter was used to express the relative expression data.

\section{Statistical analysis}

Data obtained were analyzed statistically using the program InStat (GraphPad Software). Data were examined by analysis of variance (ANOVA) followed by the Student t-test post hoc to determine possible between-group differences. The results were considered significant when $\mathrm{P}<0.05$.

\section{Results $: \because$.}

\section{Time course of edema formation}

Carrageenan-induced edema in the subplantar region of rat paw was used as a model to determine temporal relationships between edema formation and expression of prekallikreins at the site of peripheral inflammation. Under the conditions used for carrageenan-induced inflammation, swelling of the paw occurred rapidly after carrageenan injection with an increase in volume at 1 hour from $0.03 \mathrm{ml}$ (groups $\mathrm{A}_{1}$ and $\mathrm{A}_{3}$ ) to $1.15 \mathrm{ml}$ (group $\mathrm{A}_{2}$ ) by a plethysmometer measurement. Swelling reached its peak at 2 hours $(2.75 \mathrm{ml})$ and remained elevated until the last measurement at 4 hours. After the $3^{\text {th }}$ and $4^{\text {th }}$ hours of carrageenan inoculation, the paw edema of animals from group $\mathrm{A}_{2}$ were $1.47 \pm 0.11$ and $0.99 \pm 0.29 \mathrm{ml}$, respectively. In animals that received only saline inoculation (group $A_{1}$ ), edema formation was not observed.

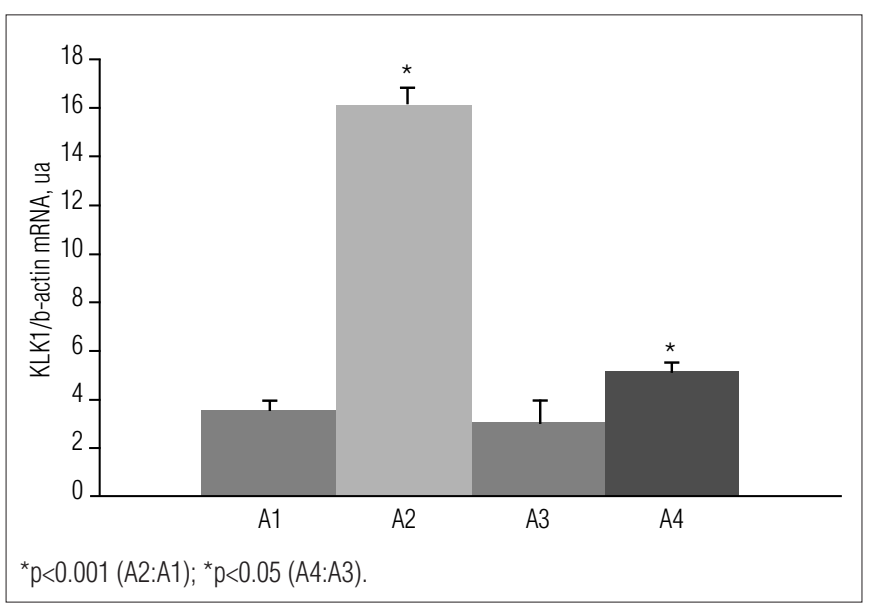

Figure 1. Quantification of tissue prekallikrein mRNA by Real time PCR. Tissue prekallikrein expression was normalised using $\beta$-actin as endogenous control and expressed as an arbitrary unit. Experimental groups ( $n=10$ per group): $A 1$ (saline only), A2 (carrageenan only), A3 (laser irradiation only) and A4 (carrageenan + laser irradiation). Tissue prekallikrein expression was induced after carrageenan injection. LLLT was able to decrease tissue prekallikrein mRNA expression.

\section{Effect of LLLT on edema formation induced by Carrageenan}

At the first hour of carrageenan-induced inflammation, the rat paw was irradiated with LLLT with a wavelength of $660 \mathrm{~nm}$ $\left(\mathrm{A}_{4}\right)$, with energy density of $7.9 \mathrm{~J} / \mathrm{cm}^{2}$. A significantly decrease in the edema evolution was observed in the second hour after laser irradiation of $660 \mathrm{~nm}$. A decrease in the edema evolution was maintained 3 hours after laser irradiation in the $\mathrm{A}_{4}$ (0.76 ml), when compared to the $A_{2}$ group $(2.75 \mathrm{ml})$. In the $1^{\text {st }}, 3^{\text {rd }}$ and $4^{\text {th }}$ hours, $A_{4}$ group animals presented the following edema volumes: $0.51 \pm 0.08 ; 0.37 \pm 0.12$ and $0.22 \pm 0.05$, respectively. No significant difference was observed between $A_{1}$ and $A_{3}$ groups.

\section{Effect of LLLT on mRNA Expression of the Tissue and Plasma Prekallikreins in Inflamed Paw}

Expression of tissue and plasma prekallikreins was determined by RT-PCR. Data were expressed as the relative expression of mRNA 4 hours after carrageenan-induced inflammation and was compared with the saline group. In the animal group receiving only carrageenan $\left(\mathrm{A}_{2}\right)$, tissue prekallikreins mRNA expression presented a pronounced increase (16.2 \pm 0.8$)$ when compared to control group $\left(A_{1}\right)(3.6 \pm 0.4 ; p<0.001$; Figure 1$)$. These data show an increase in tissue prekallikrein mRNA expression around 4.5 times after carrageenan-induced inflammation. LLLT promoted a marked decrease in the tissue prekallikrein expression. An important reduction in the tissue prekallikrein mRNA expression by LLLT using laser of $660 \mathrm{~nm}$ was also observed $(5.2 \pm 0.5 ; \mathrm{p}<0.05)$.

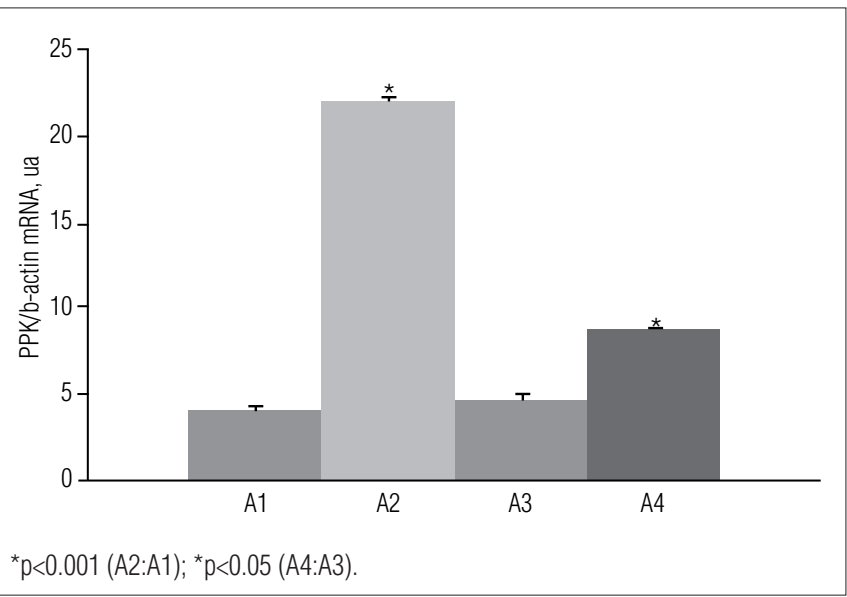

Figure 2. Quantification of plasma prekallikrein mRNA by Real time PCR. Tissue prekallikrein expression was normalised using $\beta$-actin as endogenous control and expressed as an arbitrary unit. Experimental groups ( $n=10$ per group): A1 (saline only), A2 (carrageenan only), A3 (laser irradiation only) and A4 (carrageenan + laser irradiation). Plasma prekallikrein expression was induced after carrageenan injection. LLLT was able to decrease plasma prekallikrein mRNA expression. 
Concerning to the plasma kallikrein mRNA expression, carrageenan induced its expression significantly $\left(A_{2} ; 22.1 \pm 0.3\right)$ when compared to the control group $\mathrm{A}_{1}(4.2 \pm 0.2 ; \mathrm{p}<0.001)$. Plasma prekallikrein mRNA amount was diminished after LLLT $(9.1 \pm 0.1 ; \mathrm{p}<0.05$; Figure 2$)$. LLLT only ( $\mathrm{A}_{3}$ group) was unable to modulate tissue and plasma prekallikreins mRNA expression (Figures 1 and 2). The saline inoculation was also incapable to alter mRNA levels of prekallikreins.

\section{Discussion $\because:$.}

Recently, the search for the understanding of the mechanisms by which LLLT behave on the tissues, as well as the determination of the most appropriate wavelength, number of applications, period of irradiation and energy density has been increased $^{16}$.

Our results demonstrated an increase of paw volume characterized as edema, after carrageenan-induced inflammation. It has been reported that one of the principal factors responsible by starting the inflammation event is the presence of inflammatory cells into the damage site, due to the interaction between an inflamed tissue and the leukocytes from bloodstream. After an inflammatory stimuli, vascular endothelium starts to express adhesion molecules that facilitates the migration of inflammatory cell into the inflamed tissue $e^{23,24}$. In addition, inflammatory mediators are released by resident cells, such as prostaglandins $\left(\mathrm{PGE}_{2}\right)$, tromboxane $\left(\mathrm{TXA}_{2}\right)$, leukotrienes $\left(\mathrm{LTD}_{4}\right)$ nitric oxide (NO), tumor necrosis factor (TNF- $\alpha$ ) and interleukins (IL-1 $\beta$ and IL-6). These mediators modified the vascular tonus through vasodilatation which contributes to the increase of vascular permeability and, consequently, the increase of the number of inflammatory cells (monocytes and neutrophils) in the site of injury ${ }^{25}$. While macroscopic examination showed markedly paw swelling of carrageenaninjected paw, histopathological examinations of paw sections usually show pronounced inflammatory reaction induced by carrageenan and is characterized by accumulation of polymorphonuclear leukocyte in interstitial tissue and between muscle bundles as well (for review, see Morris ${ }^{26}$ ).

Real Time PCR provides a clinical diagnosis with the ability to specifically target a particular sequence of human or pathogen DNA or RNA and amplify it to a level that can be detected and measured. Moreover, it is a fast, accurate, and highly sensitive method that can be used for a broad range of genetic tests. Here we used the PCR technology in order to detect changes in mRNA content after laser therapy, that can provide new information about the action of laser therapy in the irradiated tissue and the its further consequences. Recently, we use the same procedure to demonstrate that LLLT can alter pro- inflammatory cytokines such as TNF- $\alpha$, IL-1 $\beta$ and IL-6 and COX mRNA expression in inflamed tissue ${ }^{21,27}$. Thus, we suggested that the anti-inflammatory effect of LLLT can be due to the modulation of the inflammatory response through steps related to mediator's activation. Probably, the effect of LLLT on the mRNA expression can be due to inhibition of not just one cytokine in each time, but modulating the TNF- $\alpha$ mRNA and, consequently, reducing the IL-1 $\beta$ mRNA expression. It has been reported that the alterations promoted by IL- $1 \beta$ during the inflammatory process are diminished in the animals treated with either a drug anti-TNF- $\alpha$ or antagonist of his receptor. Aimbire et al. $^{28}$ have demonstrated that LLLT reduced both the TNF- $\alpha$ level and the hemorrhagic lesion in an acute lung inflammation model. It has been reported that the anti-inflammatory effect of LLLT is related to activation of transcription factors such as the NF-кB. This transcription factor stimulates the increase of mRNA expression to TNF- $\alpha$, IL- $1 \beta$ and IL- $6^{29}$.

Components of kallikrein-kinin system such as kinin B1 and $\mathrm{B} 2$ receptors were also related to LLLT action. A decrease in kinin B1 receptor mRNA amount after LLLT was observed using laser with a wavelength of either 660 or $684 \mathrm{~nm}$. Kinin B1 receptor mRNA expression is relevant in inflammation models, since its induction is modulated by cytokines such as IL- $1 \beta$ and TNF- $\alpha^{30}$. Kinin B2 receptor mRNA expression was also diminished after $\mathrm{LLLT}^{31}$. In addition, there appears to be an inter-relationship between cytokines and kinins in the inflammatory process. Kinins induce the release of cytokines, and cytokines have been shown to augment the effects of kinins. This may lead to an enhancement and perpetuation of the inflammatory process ${ }^{32}$.

This study is the first to report the modulation of mRNA prekallikrein expression by LLLT and reinforces the involvement of kallikrein-kinin system in the anti-inflammatory action of LLLT. Accumulating evidence indicates that prekallikreins are involved in many pathologic conditions. Evidences suggest an important role for kinins in the generation of pain, swelling and the cellular damage associated with inflammatory joint disease $\mathrm{e}^{3}$.

Kinins are considered to be pro-inflammatory peptides for a variety of reasons. They stimulate $\mathrm{c}$ fibers in the synovium that cause pain and increase extravasation of fluid to produce swelling. Kinins possess the capacity to release neurotransmitters (substance P and acetylcholine) and a second wave of mediators (interleukin-1, tumor necrosis factor, interleukin-8, prostaglandins and leukotrienes) ${ }^{33}$.

The use of kallikrein as a therapeutic treatment is increasing in many conditions, especially treatments aiming to restore the impaired cardiac function after post-infarction heart failure ${ }^{34}$ and promoting neovascularization in the limb ischemia ${ }^{35}$.

In summary, kallikrein cascade plays a significant role in the molecular events of the inflammatory response, since it 
is considered to initiate and maintain systemic inflammatory responses and immune-modulated disorders. A primary event is the chemotactic attraction of neutrophils which deliver the kallikrein-kinin cascade to sites of cellular injury and carcinogenic transformation of cells ${ }^{36}$.

The present study established the involvement of the tissue and plasma prekallikreins expression in acute inflammatory response. Moreover, it shows that tissue and plasma prekallikreins mRNA expression is modulated by irradiation using LLLT. Together, our results suggest that LLLT is an alternative therapy that inhibits the pro-inflammatory actions of kallikrein-kinin system at transcriptional levels. Furthermore, the use of Real Time PCR to determine the LLLT impact on cellular pathophysiology is highly recommended, since it combines the clinical observations to basic research in a way to understand the beneficial effects of the laser therapy.

\section{Study limitations}

As mRNAs are protein precursors, the amount of prekallikreins mRNAs measured by quantitative PCR is the first step of the importance of these peptides in several diseases and inflammation, like it was shown in this study. However, several mechanisms can silent or even destroy mRNA before translation, what could cause an imbalance between mRNA and protein content. Further methods to establish protein expression are been conducted in our laboratory to answer these questions. Other important limitation is that various studies lack standardization of the LLLT protocols with enormous variation in parameters (such as wavelengths, energy and power densities, wave modes, number of treatments), which makes it difficult to assess the optimum treatment parameters in each case.

\section{Future perspectives}

As mentioned above, there is an enormous variation in laser application parameters. Studies following the same parameters used in this study are been performed and additional information is expected from groups treated with carrageenan and laser irradiation after 3, 7 and 14-day protocols.

\section{Acknowledgements $: \because$.}

To Coordenação de Aperfeiçoamento de Pessoal de Nível Superior (CAPES), Conselho Nacional de Desenvolvimento Científico e Tecnológico (CNPq), Fundação de Amparo à Pesquisa do Estado de São Paulo (FAPESP) and Universidade Nove de Julho (UNINOVE) for the financial support.

\section{References $: \because$.}

1. Moreau ME, Garbacki N, Molinaro G. Brown NJ, Marceau F, Adam A. The kallikrein-kinin system: current and future pharmacological targets. J Pharmacol Sci. 2005;99(1):6-38.

2. Sharma JN. Hypertension and the bradykinin system. Curr Hypertens Rep. 2009;11(3):178-81.

3. Yousef GM, Diamandis EP. An overview of the kallikrein gene families in humans and other species: emerging candidate tumour markers. Clin Biochem. 2003;36(6):443-52.

4. Yoon H, Laxmikanthan G, Lee J, Blaber SI, Rodriguez A, Kogot JM, et al. Activation profiles and regulatory cascades of the human kallikrein-related peptidases. J Biol Chem. 2007;282(44):31852-64

5. Emami N, Diamandis EP. Human tissue kallikreins: a road under construction. Clin Chim Acta. 2007:381(1):78-84

6. Clements JA, Willemsen NM, Myers SA, Dong Y. The tissue kallikrein family of serine proteases: functional roles in human disease and potential as clinical biomarkers. Crit Rev Clin Lab Sci. 2004:41(3):265-312

7. Houle S, Papez MD, Ferazzini M, Hollenberg MD, Vergnolle N. Neutrophils and the kallikreinkinin system in proteinase-activated receptor 4-mediated inflammation in rodents. $\mathrm{Br} \mathrm{J}$ Pharmacol. 2005;146(5):670-8.

8. McDougall JJ, Zhang C, Cellars L, Joubert E, Dixon CM, Vergnolle N. Triggering of proteinase-activated receptor 4 leads to joint pain and inflammation in mice. Arthritis Rheum. 2009;60(3):728-37.

9. Fink E, Bhoola KD, Snyman C, Neth P, Figueroa CD. Cellular expression of plasma prekallikrein in human tissues. Biol Chem. 2007;388(9):957-63.

10. Di Rosa M. Biological properties of carrageenan. J Pharm Pharmacol. 1972;24(2):89-102

11. Winter CA, Risley EA, Nuss GM. Carrageenin-induced oedema in the hind paw of the rat as an assay for anti-inflammatory drugs. PNAS. 1962;111:544-7.
12. Colville-Nash PR, Gilroy DW. COX-2 and the cyclopentenone prostaglandins - a new chapter in the book of inflammation? Prostaglandins Other Lipid Mediat. 2000;62(1):33-43.

13. Sulaiman MR, Zakaria ZA, Adilius M, Mohamad AS, Ismail M, Israf DA. Antinociceptive and antiinflammatory effects of the ethanol extract of Alpinia conchigera Griff. leaves in various animal models. Methods Find Exp Clin Pharmacol. 2009;31(4):241-7.

14. Kandolf-Sekulovic L, Kataranovski M. Pavlovic MD. Immunomodulatory effects of low-intensity near-infrared laser irradiation on contact hypersensitivity reaction. Photodermatol Photoimmunol Photomed. 2003;19(4):203-12

15. Vladimirov YA, Osipov AN, Klebanov Gl. Photobiological principles of therapeutic applications of laser radiation. Biochemistry (Mosc). 2004;69(1):81-90.

16. Bjordal JM, Johnson MI, Iversen V, Aimbire F, Lopes-Martins RAB. Low-level laser therapy in acute pain: a systematic review of possible mechanisms of action and clinical effects in randomized placebo-controlled trials. Photomed Laser Surg. 2006;24(2):158-68.

17. Honmura A, Yanase M, Obata J, Haruki E. Therapeutic effect of Ga-Al-As diode laser irradiation on experimentally induced inflammation in rats. Lasers Surg Med. 1992;12(4):441-9.

18. de Morais NC, Barbosa AM, Vale ML, Villaverde AB, de Lima CJ, Cogo JC, et al. Antiinflammatory effect of low-level laser and light-emitting diode in zymosan-induced arthritis. Photomed Laser Surg. 2010;28(2):227-32.

19. Boschi ES, Leite CE, Saciura VC, Caberlon E, Lunardelli A, Bitencourt S, et al. Anti-inflammatory effects of low-level laser therapy $(660 \mathrm{~nm})$ in the early phase in carrageenan-induced pleurisy in rat. Lasers Surg Med. 2008;40(7):500-8.

20. Mohammadi Z. Laser applications in endodontics: an update review. Int Dent J. 2009;59(1):35-46

21. Albertini R, Villaverde AB, Aimbire F; Bjordal JM, Brugnera Junior A, Mittimann J, et al. Cytokine mRNA expression is decreased in the subplantar muscle of rat paw subjected to carrageenaninduced inflammation after low-level laser therapy. Photomed Laser Surg. 2008;26(1):19-24. 
22. Fereidoni M, Ahmadiani A, Semnanian S, Javan M. An accurate and simple method for measurement of paw oedema. J Pharmacol Toxicol Methods. 2000;43(1):11-4.

23. Madan B, Mandal BC, Kumar S, Ghosh B. Canscora decussata (Roxb.) Schult (Gentianaceae) inhibits LPS-induced expression of ICAM-1 and E-selectin on endothelial cells and carageenaninduced paw-edema in rats. J Ethnopharmacol. 2003;89(2-3):211-6.

24. Pierce JW, Schoenleber R, Jesmok G, Best J, Moore SA, Collins T, et al. Novel inhibitors of cytokine-induced IkappaBalpha phosphorylation and endothelial cell adhesion molecule expression show anti-inflammatory effects in vivo. J Biol Chem. 1997;272(34):21096-103.

25. Schröder AK, von der Ohe M, Kolling U, AltstaedtJ, Uciechowski P, Fleischer D, etal. Polymorphonuclear leucocytes selectively produce anti-inflammatory interleukin-1 receptor antagonist and chemokines, but fail to produce pro-inflammatory mediators. Immunology. 2006;119(3): 317-27.

26. Morris CJ. Carrageenan-induced paw edema in the rat and mouse. Methods Mol Biol. 2003;225:115-21.

27. Albertini R, Aimbire F, Villaverde AB, Silva JA Jr, Costa MS. COX-2 mRNA expression decreases in the subplantar muscle of rat paw subjected to carrageenan-induced inflammation after low level laser therapy. Inflamm Res. 2007;56(6):228-9.

28. Aimbire F, Bjordal JM, Iversen VV, Albertini R, Frigo L, Pacheco MT, et al. Low level laser therapy partially restores trachea muscle relaxation response in rats with tumor necrosis factor alphamediated smooth airway muscle dysfunction Lasers Surg Med. 2006;38(8):773-8.
29. Linard C, Marquette C, Mathieu J, Pennequin A, Clarencon D, Mathe D. Acute induction of inflammatory cytokine expression after gamma-irradiation in the rat: effect of an NF-kappaB inhibitor. Int J Radiat Oncol Biol Phys. 2004;58(2):427-34.

30. Couture R, Harrisson M, Vianna RM, Cloutier F. Kinin receptors in pain and inflammation. Eur J Pharmacol. 2001;429(1-3):161-76.

31. Bortone F, Santos HA, Albertini R, Pesquero JB, Costa MS, Silva Jr JA. Low level laser therapy modulates kinin receptors mRNA expression in the subplantar muscle of rat paw subjected to carrageenan-induced inflammation. Int Immunopharmacol. 2008;8(2):206-10.

32. Cassim B, Mody G, Bhoola K. Kallikrein cascade and cytokines in inflamed joints. Pharmaco Ther. 2002;94(1-2):1-34.

33. Bhoola KD, Elson CJ, Dieppe PA. Kinins--key mediators in inflammatory arthritis? $\mathrm{Br} \mathrm{J}$ Rheumatol. 1992;31(8):509-18

34. Yao YY, Yin $\mathrm{H}$, Shen $\mathrm{B}$, Chao L, Chao J. Tissue kallikrein and kinin infusion rescues failing myocardium after myocardial infarction. J Card Fail. 2007;13(7):588-96.

35. Smith RS Jr, Gao L, Chao L, Chao J. Tissue kallikrein and kinin infusion promotes neovascularization in limb ischemia. Biol Chem. 2008;389(6):725-30.

36. Bhoola K, Ramsaroop R, Plendl J, Cassim B, Dlamini Z, Naicker S. Kallikrein and kinin receptor expression in inflammation and cancer. Biol Chem. 2001;382(1):77-89. 